\title{
Determinants of Sharia Banking Market Share Growth in Indonesia
}

\author{
Muh. Khairul Fatihin ${ }^{1}$,Nizar Hosfaikoni Hadi² \\ 1,2 Department of Islamic Economics, Faculty of Economics and Business, \\ Universitas Airlangga \\ Email: nizar.hosfaikoni.hadi-2018@pasca.unair.ac.id (correspondence author)
}

\begin{abstract}
The purpose of this paper is to investigate the variables that influence Islamic banking markets in Indonesia. The research data were obtained directly from the website of the Central Statistics Agency (BPS) and the financial services authority(OJK) from 2011-2018 which were taken on a quarterly basis. This study uses multiple regression analysis to analyze the factors that have an impact on the market share of Islamic banks in Indonesia. The variable that can affect Islamic banking marketshare in Indonesia is the liquidity ratio (FDR). While other variables such as the default rate (NPF), profit rate (ROA), economic growth (GDP) and conventional bank interest rates (INT) do not affect Islamic banking. The results suggest that Islamic banking regulates liquidity ratios (FDR) so that Islamic banking can effectively increase its market. This study complements previous research so that Islamic banking maintains a liquidity ratio in order to remain balanced.
\end{abstract}

Keywords: marketshare, Islamic banking, FDR, GDP, ROA 


\section{Introduction}

The sharia banking industry is experiencing slow development despite having established a blueprint policy to develop the sharia banking industry (Ismal 2013) Sharia banking takes eight years to reach the $5 \%$ market share target obtained in 2016, this is due to the fact that some of the existing policies do not fully support sharia banking both in terms of regulation and especially the capital that is needed by sharia banks to improve services to the public. This can also be interpreted that the government's trust in Islamic banking is still low (Rusydiana 2016) The last sharia banking market share growth moved up to $5.82 \%$ in 2018 so that sharia banking growth did not go as expected.

Table 1.

Development of Islamic banking market share

\begin{tabular}{lllllllll}
\hline Year & 2011 & 2012 & $\mathbf{2 0 1 3}$ & $\mathbf{2 0 1 4}$ & $\mathbf{2 0 1 5}$ & $\mathbf{2 0 1 6}$ & $\mathbf{2 0 1 7}$ & $\mathbf{2 0 1 8}$ \\
\hline $\begin{array}{l}\text { Market } \\
\text { Share }\end{array}$ & 3,98 & 4,58 & 4,89 & 4,85 & 4,83 & 5,3 & 5,74 & 5,82 \\
\hline
\end{tabular}

Source : financial services authority (OJK) 2011-2018

Indonesia is a country with the largest Islamic economic potential in the world but the market share of Islamic banks in Indonesia is currently lagging far behind other countries such as Malaysia and Singapore (Sari, Bahari, and Hamat 2013),(Wouters 2007) At present Indonesia is still in the ninth position and tends to be a spectator in the development of Islamic economics. There are several other problems faced by Islamic banking such as regulations that do not support the development of Islamic banking, although the determining factor for the development of Islamic banking in each country is government regulation. (Bitar, Hassan, and Hippler 2018) Like in Malaysia and Iran where Iran has $100 \%$ market share of Islamic banking because it is supported by government policies that are pro to Islamic banking. This shows that the progress of Islamic banking is very much determined by government regulations so that to advance Islamic banking the government must create a good Islamic banking climate. (Bitar, Hassan, and Hippler 2018)

Many prominent figures in Islamic economics give advice to the government to increase economic growth through a spin off, but the performance of Islamic banking is still normal without any expected progress. On the other hand these proposals contain problems that must be anticipated. For example, the government policy on spin-offs to 
accelerate the market share of Islamic banking raises a discrepancy with what was expected. there is no difference in the performance of Islamic banks between pre and post spin-o (M. Al Arif et al. 2017); (Haribowo 2016) So, the solution that was raised, namely by holding Islamic banking by the government (Karim 2019).

There are several Government strategies in developing Islamic banking such as mergers and spin-offs. But the merger strategy can cause problems such as stagnant growth of Islamic banking for 3 years and administrative and management arrangements that require a long time.

This research will investigate the variables that influence the Islamic banking market share in Indonesia. The results of this study are expected to be a consideration for policy makers. Policy makers can develop appropriate policies to accelerate the growth of the Islamic banking industry.

\section{Literature Review}

Several factors determine the market share of Islamic banking, such as internal factors and external factors.(Syafrida and Abror 2011), (Saputra 2014), and (Purboastuti, Anwar, and Suryahani 2015) concluded that several internal factors affect market share, such as proitabilitas Return on Asset (ROA), Non Performing Financing (NPF), and Financing Deposit Ratio (FDR).(Purboastuti, Anwar, and Suryahani 2015) (Rahman 2016) also found that the level of default, the ratio of operational efficiency, and capital requirements again had an impact on the market share of Islamic banks. Market share will be one of the factors determining the performance of Islamic banks. (Mirzaei, Ali; Liu, Guy; and Moore 2011) states that profitability will affect Islamic banking marketshare. In general, an increase in the market share of Islamic banking will increase the contribution of Islamic banking to the economy.

Saputra (2014) found that ROA, and FDR are elements that positively and significantly affect marketshare. other than that (Purboastuti, Anwar, and Suryahani 2015) also find profitability ratios (ROA), default levels (NPL), and liquidity ratios (FDR) effect on market share.

\section{Research Methodology}

This study uses secondary data collected from Islamic bank financial statements, central statistics and OJK Statistics. This study uses a quantitative approach. The method used in this research is multiple regression analysis. Multiple regression is used to analyze the factors that have an impact on the market share of Islamic banks in Indonesia. This research is aimed at Islamic Commercial Banks (BUS) and Islamic people's credit banks (BPRS) from 2011-2018 by taking quarterly data. (OJK , 2018) 


\section{Result And Discussion}

Based on research results, Financing deposit ratio (FDR) is a variable that has a significant effect on the Islamic banking market share as well as previous studies that the liquidity ratio has an influence on the Islamic banking marketshare (Syafrida and Abror, 2011). On the other hand, variables such as profit (Return of Asset) NPF, Intrest rate dan gross domestic produc (GDP) has no influence on Islamic banking market share.

Table 2

\begin{tabular}{llll}
\hline \hline F-statistic & 0.965188 & Prob. $F(2,24)$ & 0.3952 \\
Obs*R-squared & 2.382227 & Prob. Chi-Square(2) & 0.3039 \\
\hline \hline
\end{tabular}

From the above table, we can find out the ProbabilityObs * RSquared value $>a=0.05$

Therefore, it can be concluded that this model does not occur autocorrelation problems.

Table 3

Heteroskedasticity Test: White

\begin{tabular}{llll}
\hline \hline F-statistic & 0.761775 & Prob. F(5,26) & 0.5855 \\
Obs*R-squared & 4.088847 & Prob. Chi-Square(5) & 0.5367 \\
Scaled explained SS & 3.433439 & Prob. Chi-Square(5) & 0.6335
\end{tabular}

White Heteroscedasticity probability of $0.5367>$ this shows the model does not contain heteroscedasticity problems in other words do not experience homogenostisidas.

Table 4

\begin{tabular}{crrrr}
\hline \hline Variable & Coefficient & Std. Error & t-Statistic & Prob. \\
\hline \hline C & 7.128088 & 1.219346 & 5.845826 & 0.0000 \\
NPF & -0.033421 & 0.027580 & -1.211774 & 0.2365 \\
FDR & -0.013671 & 0.003075 & -4.445586 & 0.0001 \\
GDP & -0.062373 & 0.110314 & -0.565411 & 0.5766 \\
INT & -0.025603 & 0.017706 & -1.445972 & 0.1601 \\
ROA & 0.075307 & 0.074953 & 1.004729 & 0.3243 \\
\hline \hline
\end{tabular}

From the table above, the liquidity ratio has a significant negative effect on the Islamic banking market share with a FDR coefficient of $-0.003 \%$ so that every $1 \%$ increase in liquidity will reduce the Islamic banking market share because the total financing will decrease so Islamic banks need to increase their financing. Contrary, if the liquidity ratio is reduced by $1 \%$, it will increase the Islamic banking market share by $0.03 \%$. this result is consistent with (Syafrida and Abror 2011) and (Rahman 2016) liquidity ratio has a 
negative influence on the market share of Islamic banking. (Saputra 2014) also found that the liquidity ratio also influences in determining the market share of Islamic banking. (Purboastuti, Anwar, and Suryahani 2015) find different results. he found that the liquidity ratio had no impact on the market share of Islamic banks. The result might be due to data differences. his research uses monthly data on sharia bank industry statistics

Other variables such as the default rate (measured by NPF) do not have an impact on the market share of Islamic banking, in contrast to the results of research conducted by (M. Al Arif et al. 2017) The difference in results may be due to differences in the data used. The study uses monthly data from January 2009 to December 2017. In addition, the profit ratio (measured by ROA) has no impact on the market share of Islamic banks. (M. N. R. Al Arif and Rahmawati 2018) found the same thing that profitability ratios had no impact on the Islamic banking market share. on the other hand Purboastuti et al. (2015) find different results. They found that the profitability ratio had an impact on the market share of Islamic banks. The profitability ratio is one of the financial indicators to explain the growth of Islamic banks. the higher the profitability ratio, the more profitable the Islamic banking industry.

Macroeconomic variables such as economic growth as measured by (GDP) and interest rates also do not affect the Islamic banking market share. This is different from (M. N. R. Al Arif and Rahmawati 2018) shows that interest rates affect the Islamic banking market share. Islamic banking market share is also very dependent on government policy (Bitar, Hassan, and Hippler 2018) . Government support will greatly affect the sharia banking marketshare because the main indicator of decision making by sharia banks in making decisions is government policy. This also indicates that the progress of the Islamic banking market share depends on the business climate created by the government.

\section{Conclusions And Recommendations}

The variable that affects the Islamic banking market share is Financing to Deposit Ratio (FDR while variables such as NPF return (return of assets), Intrest rate and gross domestic product (GDP) have no influence on Islamic banking marketshare. While other variables such as the default rate (NPF), profit rate (ROA), economic growth (GDP) and conventional bank interest rates (INT) do not affect Islamic banking. This research shows that Islamic banks need to increase financing and pay close attention to their liquidity ratios in order to increase market share.

\section{REFERENCES}

[1]Arif, M Nur Rianto Al, and Yuke Rahmawati. 2018. "Determinant Factors of Market Share: Evidence from the Indonesian Islamic Banking Industry." Problems and Perspectives in Management 16 (1): 392.

[2]Arif, Muhammad Al, Nachrowi Nachrowi, Mustafa Nasution, and T M Mahmud. 2017. "The Islamic Banking Spin-off: Lessons from Indonesian Islamic Banking 
Experiences." Journal of King Abdulaziz University: Islamic Economics 30 (2).

[3]Bitar, Mohammad, M Kabir Hassan, and William J Hippler. 2018. "The Determinants of Islamic Bank Capital Decisions." Emerging Markets Review 35: 48-68.

[4]Haribowo, Ismawati. 2016. "The Indonesian Islamic Bank's Spin-off: A Study in Regional Development Banks." Al-lqtishad: Jurnal Ilmu Ekonomi Syariah 9 (1): 5368.

[5] Ismal, Rifki. 2013. Islamic Banking in Indonesia: New Perspectives on Monetary and Financial Issues. John Wiley \& Sons.

[6]Karim, Adiwarman A. 2019. Ekonomi Makro Islami. PT RajaGrafindo Persada.

[7]Mirzaei, Ali; Liu, Guy; and Moore, Tomoe. 2011. Does Market Share Matter on Bank's Profitability and Stability?: Emerging versus Advances Economies. Bruney University, 1995.

[8]OJK. 2018. "Islamic Banking Statistics, January 2011 -Juli 2018." http://www.ojk.go.id.

[9]Purboastuti, Nurani, Nurul Anwar, and Irma Suryahani. 2015. "Pengaruh Indikator Utama Perbankan Terhadap Pangsa Pasar Perbankan Syariah (Effect of Key Banking Indicators on Sharia Banking Market Share)." JEJAK 8 (1).

[10]Rahman. 2016. "Analysis of Factors That Influence The Islamic Bank's Market Share." Analytica Islamica, 291-314.

[1 1]Rusydiana, Aam Slamet. 2016. "Analisis Masalah Pengembangan Perbankan Syariah Di Indonesia: Aplikasi Metode Analytic Network Process(Analysis of the Problem of Developing Islamic Banking in Indonesia: Application of the Analytic Network Process Method)." Esensi: Jurnal Bisnis Dan Manajemen 6 (2): 237-46.

[12]Saputra, Bambang. 2014. "Faktor-Faktor Keuangan Yang Mempengaruhi Market Share Perbankan Syariah Di Indonesia(Financial Factors That Affect the Market Share of Islamic Banking in Indonesia)." Akuntabilitas 7 (2): 123-31.

[13]Sari, Mutiara Dewi, Zakaria Bahari, and Zahri Hamat. 2013. "Perkembangan Perbanakan Syariah Di Indonesia: Suatu Tinjauan (Development of Islamic Banking in Indonesia: An Overview)." Jurnal Aplikasi Bisnis 3 (2): 120-38.

[14]Syafrida, Ida, and Ahmad Abror. 2011. "Faktor-Faktor Internal Dan Eksternal Yang Mempengaruhi Pertumbuhan Aset Perbankan Syariah Di Indonesia (Internal and External Factors That Affect the Growth of Sharia Banking Assets in Indonesia)." Jurnal Ekonomi \& Bisnis PNJ 10 (1): 13446.

[15]Wouters, Paul. 2007. "Islamic Banking in Turkey, Indonesia and Pakistan: A Comparison with Malaysia." Islamic Finance News 4 (42). 